\title{
SEROLOGICAL, EPIDEMIOLOGICAL AND MOLECULAR ASPECTS OF HEPATITIS C VIRUS INFECTION IN A POPULATION FROM LONDRINA, PR, BRAZIL, 2001-2002
}

\author{
Ingridt Hildegard VOGLER(1), Anna NISHIYA(2), Helena Kaminami MORIMOTO(1,3), Edna Maria Vissoci REICHE(1,3), André Luiz BORTOLIERO(4,5),
} Tiemi MATSUO(6), Ester Cerdeira SABINO(2) \& Adelaide Jose VAZ(7)

\begin{abstract}
SUMMARY
Serological, epidemiological and molecular aspects of hepatitis C virus (HCV) infection were evaluated in 183 subjects from Londrina, Paraná, Brazil, and adjacent areas. Serum samples which tested anti-HCV positive by microparticle enzyme immunoassay (MEIA) obtained from eight patients with chronic hepatitis C, 48 blood donors, and 127 patients infected with the human immunodeficiency virus (HIV) were submitted to another enzyme immunoassay (ELISA) and to the polymerase chain reaction (PCR). About $78.7 \%$ of samples were also reactive by ELISA, with the greater proportion $(70.8 \%)$ of discordant results verified among blood donors. A similar finding was observed for HCV-RNA detection by PCR, with 111/165 (67.3\%) positive samples, with higher rates among HIV-positive subjects and patients with chronic hepatitis than among blood donors. Sixty-one PCRpositive samples were submitted to HCV genotyping, with 77.1, 21.3 and 1.6\% of the samples identified as types 1, 3 and 2, respectively. Finally, analysis of some risk factors associated with $\mathrm{HCV}$ infection showed that intravenous drug use was the most common risk factor among HIV/HCV co-infected patients, while blood transfusion was the most important risk factor in the group without HIV infection. The present study contributed to the knowledge regarding risk factors associated with HCV infection and the distribution of HCV genotypes in the population evaluated.
\end{abstract}

KEYWORDS: Hepatitis C virus; Anti-HCV; Genotypes; Epidemiology.

\section{INTRODUCTION}

About 170 million people all over the world are infected with hepatitis $\mathrm{C}$ virus $(\mathrm{HCV})$, although many ignore such fact ${ }^{30}$. In most cases, the infection develops as an asymptomatic clinical picture but with severe consequences, since about $80 \%$ of the infected subjects develop chronic hepatitis, cirrhosis or hepatocellular carcinoma ${ }^{1628}$.

Co-infection of HCV-infected subjects with the human immunodeficiency virus (HIV) has important implications for the prognosis and management of both diseases. These subjects show elevated alanine aminotransferase levels and are at a higher risk of developing fibrosis, cirrhosis, liver failure or hepatocellular carcinoma than subjects infected only with $\mathrm{HCV}^{6}$; in addition, they show a higher risk of developing hepatic toxicity related to the use of highly active antiretroviral therapy than patients infected only with HIV $\mathrm{HV}^{5,26}$.

The use of the polymerase chain reaction (PCR) for the detection of HCV-RNA allows the identification of the presence of active HCV infection. However, RNA levels may show fluctuations with nondetectable periods even in patients not submitted to interferon therapy ${ }^{7}$.
Patient counseling regarding the risk-benefit of treatment also requires analysis of a liver biopsy and the determination of the HCV genotype. Differences in the response to treatment depending on the HCV genotype have been observed, with type 1 being more resistant than types 2 and $3^{19}$. Genotyping based on the amplification of the 5' untranslated region (5'-UTR) has the advantage that it can be performed on PCR amplification products obtained from HCV-RNA detection tests ${ }^{7,10}$.

$\mathrm{HCV}$ prevalence varies among different regions of the world or even among different groups studied. Prevalence is lower in populations highly selected by previous screening for risk factors associated with the infection, such as blood donors, and is higher among groups highly exposed to parenteral transmission of the virus, such as intravenous drug users or hemodialysis patients ${ }^{2,13,21,29}$. In Brazil, available data usually refer to large centers ${ }^{8,12,22}$. In Londrina, Paraná, data are also very scarce. PONTELLO et al. (1993) detected $1.2 \%$ positivity of antiHCV antibodies in blood donors ${ }^{23}$, and REICHE et al. (2000), studying 1,006 pregnant women assisted at a University Hospital during the period from $1996-1998$, reported $0.8 \%$ positivity determined by enzyme immunoassay (ELISA), with no confirmation of antibody specificity or determination of the presence of HCV-RNA in seropositive cases ${ }^{24}$.

(1) Laboratório de Análises Clínicas, Hospital Universitário, Universidade Estadual de Londrina, PR, Brasil.

(2) Fundação Pró-Sangue Hemocentro de São Paulo (FPS/HSP), SP, Brasil.

(3) Departamento de Patologia, Análises Clínicas e Toxicológicas, Centro de Ciências da Saúde, Universidade Estadual de Londrina, PR, Brasil.

(4) Departamento de Clínica Médica, Centro de Ciências da Saúde, Universidade Estadual de Londrina, PR, Brasil.

(5) Hemocentro Regional do Hospital Universitário, Universidade Estadual de Londrina, PR, Brasil.

(6) Departamento de Matemática Aplicada, Centro de Ciências Exatas, Universidade Estadual de Londrina, PR, Brasil

(7) Faculdade de Ciências Farmacêuticas, Universidade de São Paulo, SP, Brasil.

Correspondence to: Ingridt Hildegard Vogler, Rua Santa Ruth 40, 86027-710 Londrina, PR, Brasil, Tel: +55-43-3371-2321, Fax: +55-43-3371-2619, e-mail: vogler@uel.br 
VOGLER, I.H.; NISHIYA, A.; MORIMOTO, H.K.; REICHE, E.M.V.; BORTOLIERO, A.L.; MATSUO, T.; SABINO, E.C. \& VAZ, A.J. - Serological, epidemiological and molecular aspects of hepatitis C virus infection in a population from Londrina, PR, Brazil, 2001-2002. Rev. Inst. Med. trop. S. Paulo, 46(6):303-308, 2004.

The aim of the present study was to evaluate the serological, epidemiological and molecular aspects of HCV infection in subjects living in the Londrina region, Paraná.

\section{MATERIAL AND METHODS}

Specimens: We studied 183 samples sent to the Clinical Laboratory of the University Hospital, Londrina, PR, between December 2001 and September 2002. The samples were selected from patients attending infectious diseases ambulatories and detected anti-HCV reactive at routine laboratorial screening. These subjects ( 48 blood donors and 127 HIV-patients with serological evidence of co-infection with HCV) were undergoing their first clinical evaluation for hepatitis $\mathrm{C}$ after the anti-HCV reactive result, and their status about HCV infection was unknown. Other eight patients selected had a confirmed diagnosis of chronic hepatitis $\mathrm{C}$, and they were previously known to be HCV-RNA positive, but HCV genotype was not still determined. No patient was under interferon therapy. The study was approved by the Research Ethics Committee of the institution and all patients signed a written informed consent.

Anti-HCV screening: Anti-HCV antibodies were initially detected by an automated microparticle enzyme immunoassay (MEIA; AXSYM® HCV version 3.0, Abbott Laboratories, USA), the method routinely used in that laboratory, and confirmed by a second ELISA assay (Murex ${ }^{\circledR}$ anti-HCV version 4.0, Murex Biotech-Abbott, South Africa). Results were expressed as the optical density of the sample (S) divided by the cut-off value (CO). Samples were considered to be strongly reactive in one assay when showing a S/CO ratio $\geq 3.0$ or $\geq$ 5.0 in ELISA or MEIA, respectively. Samples were classified as weakly reactive when the S/CO ratio was between 1.0 and 2.9 in ELISA or between 1.0 and 4.9 in MEIA ${ }^{14,15}$. Samples with a $\mathrm{S} / \mathrm{CO}$ ratio $<1.0$ in ELISA or MEIA were considered to be non-reactive.

Detection of HCV-RNA: Samples were stored at $-20{ }^{\circ} \mathrm{C}$ and later submitted to nested-PCR using primers for the amplification of the 5 , untranslated region ( $5^{\prime}$-UTR) of HCV. The assay was performed on 165 samples; other 18 samples were stored at $4{ }^{\circ} \mathrm{C}$ for several days, and were not tested by PCR because of possible RNA degradation. Viral RNA was extracted from $100 \mu \mathrm{L}$ serum with $300 \mu \mathrm{L}$ Trizol $^{\circledR}$ (Gibco-BRL, USA), separated in an aqueous phase by chloroform addition and precipitated with isopropanol. The pellet was washed in $70 \%$ ethanol and dissolved in $12 \mu \mathrm{L}$ of a solution containing diethyl pyrocarbonate-treated water and $300 \mathrm{ng}$ of random primers (Pharmacia Biotech, Sweden $)^{4}$. After a denaturation step at $70^{\circ} \mathrm{C}$ for $10 \mathrm{~min}, \mathrm{cDNA}$ was synthesized from RNA by the addition of a solution containing $100 \mathrm{U}$ reverse transcriptase (SuperScript ${ }^{\mathrm{TM}}$ II RNase H-Reverse Transcriptase, Gibco-BRL), $50 \mathrm{mM}$ Tris- $\mathrm{HCl}, 75 \mathrm{mM} \mathrm{KCl,} 3 \mathrm{mM}$ $\mathrm{MgCl}_{2}, 10 \mu \mathrm{M}$ DTT, $5 \mathrm{U}$ RNase inhibitor, and $0.5 \mathrm{mM}$ deoxynucleoside triphosphate mix (dNTP), in a final reaction volume of $20 \mu \mathrm{L}$. The mixture was incubated at $42{ }^{\circ} \mathrm{C}$ for $90 \mathrm{~min}$ and then heated to $70{ }^{\circ} \mathrm{C}$ for 10 min. A two-round PCR was run in a final reaction volume of $50 \mu \mathrm{L}$ using a protocol including an initial cycle at $94{ }^{\circ} \mathrm{C}$ for one min and 40 cycles at $94{ }^{\circ} \mathrm{C}$ for $30 \mathrm{~s}, 55^{\circ} \mathrm{C}$ for $30 \mathrm{~s}$ and $72{ }^{\circ} \mathrm{C}$ for $30 \mathrm{~s}$, followed by a final extension cycle at $72{ }^{\circ} \mathrm{C}$ for five min. NCR1 (5'GTATCTCGAGGCGACACTCCACCATAG-3') and NCR2 (5'ATACTCGAGGTGCACGGTCTACGAGAC-3') were used as outer primers, and NCR3 (5'-CCACCATAGATCTCTCCCCTGT-3') and
NCR4 (5'-CACTCTCGAGCACCCTATCAGGCAGT-3') as inner primers. For the first amplification, $5 \mu \mathrm{L}$ of cDNA was mixed with 45 $\mu \mathrm{L}$ of a reaction mixture containing $20 \mathrm{mM}$ Tris- $\mathrm{HCl}, 50 \mathrm{mM} \mathrm{KCl}, 2$ $\mathrm{mM} \mathrm{MgCl}, 0.15 \mathrm{mM}$ dNTP mix, $1 \mathrm{U}$ Taq DNA polymerase (GibcoBRL), and 12.5 pmol of each outer primer. The second amplification was performed using $3 \mu \mathrm{L}$ of the first amplification product and a mixture of the same composition as described above, but using the inner primers, $0.2 \mathrm{mM} \mathrm{dNTP}$ mix and $1.5 \mathrm{mM} \mathrm{MgCl}$. The second PCR amplification product was separated by electrophoresis on $1.5 \%$ agarose gel stained with ethidium bromide and visualized under ultraviolet light ${ }^{9}$.

HCV genotyping: Nucleotide sequencing of HCV 5'-UTR was carried out for 61 PCR-positive samples (seven blood donors, eight chronic patients and 46 HIV-seropositive subjects). The PCR product was purified (QIAquick ${ }^{\circ}$, QIAGEN, Germany) and submitted to sequencing (ABI PRISM ${ }^{\circledR}$ Big Dye Terminator Cycle Sequencing Ready Reaction Kit, PE Applied Biosystems, USA) in an automatic GeneAmp 9600 thermal cycler using 25 cycles at $96^{\circ} \mathrm{C}$ for $10 \mathrm{~s}, 50{ }^{\circ} \mathrm{C}$ for five seconds and $60^{\circ} \mathrm{C}$ for four min. The product was precipitated with sodium acetate and ethanol, and later dissolved in loading buffer and submitted to electrophoresis in the ABI PRISM 377 DNA Sequencer (PE Applied Biosystems). The sequences obtained were edited with the SEQUENCHER program, aligned using the BIOEDIT program, and compared with published sequences available at GenBank: 1a (M62321 and D10749), 1b (D90208), 1c (D14853), 2a (D00944), 2b (D10998), 3a (D28917), 3b (D49374), 3c (D16612), 4a (Y11604), 5a (Y13184), and 6a (Y12083).

Risk factors: Subjects with detectable HCV-RNA were asked regarding possible risk factors, such as the use of intravenous drugs, blood transfusion and sexual relations with multiple partners (defined as more than 10 lifetime sexual partners) ${ }^{3}$.

Statistical analysis: Results were expressed as absolute and relative frequencies. The kappa coefficient $(\kappa)$ was used for comparison of the performance of the different assays ${ }^{17}$. Proportions were compared by the chi-square test $\left(\chi^{2}\right)$. The odds ratio (OR) and $95 \%$ confidence interval (CI) were calculated to determine the association between variables. The statistical tests were performed using the EPI-INFO program version $6.04 \mathrm{~d}$ (CDC, Atlanta, USA), and statistical significance was assessed at the 0.05 probability level in all analyses $(\mathrm{p}<0.05)$.

\section{RESULTS}

Anti-HCV screening: Of 183 anti-HCV-positive samples by MEIA, 59 (32.2\%) were weakly reactive (S/CO ratio between 1.0 and $4.9)$ and $124(67.8 \%)$ were strongly reactive $(\mathrm{S} / \mathrm{CO} \geq 5.0)$. This reactivity was confirmed in $144(78.7 \%)$ samples by a second screening assay (ELISA). Positive results by the two screening assays were observed in $22 / 59(37.3 \%)$ and $122 / 124(98.4 \%)$ samples from the weakly reactive and the strongly reactive groups, respectively. Only $29.2 \%$ (14/48) of the blood donor samples tested positive by the two assays used, in contrast to the $96.1 \%(122 / 127)$ and $100 \%(8 / 8)$ agreement between these two methods obtained for HIV-positive and HCV chronic patients, respectively $\left(\chi^{2}=95.22 ; \mathrm{p}<0.001\right)$.

PCR: HCV-RNA was detected in 111/165 (67.3\%) samples 
VOGLER, I.H.; NISHIYA, A.; MORIMOTO, H.K.; REICHE, E.M.V.; BORTOLIERO, A.L.; MATSUO, T.; SABINO, E.C. \& VAZ, A.J. - Serological, epidemiological and molecular aspects of hepatitis C virus infection in a population from Londrina, PR, Brazil, 2001-2002. Rev. Inst. Med. trop. S. Paulo, 46(6):303-308, 2004.

evaluated. PCR positivity was higher in patients with chronic hepatitis C (100\%; 8/8 samples) and HIV-positive patients (75.6\%; 96/127 samples) than in blood donors $(23.3 \% ; 7 / 30$ samples $)\left(\chi^{2}=34.19 ; \mathrm{p}<\right.$ 0.001). All PCR-positive samples were reactive in both MEIA and ELISA. A comparison between the MEIA, ELISA and PCR results is shown in Table 1.

Genotyping: HCV genotype was determined in 61/111 PCRpositive samples. Genotypes found were type $1(77.1 \%)$, followed by type $3(21.3 \%)$ and type $2(1.6 \%)$. The most common subtypes were 1a $(42.6 \%), 1 \mathrm{~b}(24.6 \%)$ and $3 \mathrm{a}(19.7 \%)$. Differentiation between subtypes $1 \mathrm{a}$ and $1 \mathrm{~b}$ was not possible in $8.2 \%$ of the samples due to the small variability in the 5'-UTR region. This was observed for the sample identified as type 2 , in which subtypes $2 \mathrm{a}$ and $2 \mathrm{~b}$ could also not be differentiated. Both subtypes $1 \mathrm{c}$ and $3 \mathrm{c}$ were also identified in only one sample $(1.6 \%)$.
Risk factors: The 111 subjects with detectable HCV-RNA were asked regarding the possible route of infection. Among the subjects co-infected with HCV/HIV, 52.1\% (50/96) were intravenous drug users, $14.6 \%$ (14/96) had received blood transfusion and 59.4\% (57/ 96) had sexual relations with multiple partners. Among the subjects infected with HCV alone, only $6.7 \%$ (1/15) were intravenous drug users, $33.3 \%$ (5/15) had received blood transfusion and 20.0\% (3/15) had multiple sexual partners. No risk factors associated with $\mathrm{HCV}$ could be identified in $53.3 \%$ and $5.2 \%$ of subjects infected with $\mathrm{HCV}$ only or co-infected with HCV/HIV, respectively (Table 2). Subtype 1 a was very common among drug users $(53.8 \%$; 14/26 samples) and subjects with multiple sexual partners (48.1\%; 13/27 samples), and subtype $1 \mathrm{~b}$ was common among recipients of blood transfusion (45.5\%; 5/11 samples).

Table 1

Comparison between the results obtained by microparticle enzyme immunoassay (MEIA), enzyme immunoassay (ELISA), and polymerase chain reaction (PCR) for 183 serum samples initially reactive in MEIA

\begin{tabular}{|c|c|c|c|c|c|}
\hline \multirow[t]{2}{*}{ MEIA } & \multirow[t]{2}{*}{ ELISA } & \multicolumn{3}{|c|}{ PCR } & \multirow[t]{2}{*}{ Total } \\
\hline & & Positive & Negative & Not done & \\
\hline \multirow[t]{3}{*}{$1 \leq \mathrm{S} / \mathrm{CO}<5^{\mathrm{b}}(\mathrm{n}=59)$} & $1<\mathrm{S} / \mathrm{CO}^{\mathrm{a}}$ & 0 & 23 & 14 & 37 \\
\hline & $1 \leq \mathrm{S} / \mathrm{CO}<3^{\mathrm{b}}$ & 1 & 8 & 0 & 9 \\
\hline & $\mathrm{S} / \mathrm{CO} \geq 3^{\mathrm{c}}$ & 5 & 7 & 1 & 13 \\
\hline \multirow[t]{3}{*}{$\mathrm{S} / \mathrm{CO} \geq 5^{\mathrm{c}}(\mathrm{n}=124)$} & $1<\mathrm{S} / \mathrm{CO}^{\mathrm{a}}$ & 0 & 1 & 1 & 2 \\
\hline & $1 \leq \mathrm{S} / \mathrm{CO}<3^{\mathrm{b}}$ & 0 & 0 & 0 & 0 \\
\hline & $\mathrm{S} / \mathrm{CO} \geq 3^{\mathrm{c}}$ & 105 & 15 & 2 & 122 \\
\hline \multicolumn{2}{|l|}{ Total } & 111 & 54 & 18 & 183 \\
\hline
\end{tabular}

MEIA: microparticle enzyme immunoassay (AXSYM ${ }^{\circledast}$, Abbott, USA); ELISA: enzyme immunoassay (Murex ${ }^{\oplus}$, Murex Biotech-Abbott, South Africa); PCR: polymerase chain reaction; S/CO: ratio of sample optical density divided by the reaction cut-off (interpreted as non-reactive ${ }^{\mathrm{a}}$, weakly reactive ${ }^{\mathrm{b}}$ or strongly reactivec); n: number of samples; MEIA (weak/strong) x PCR $(+/-): \kappa=0.682(\mathrm{p}<0.001)$; MEIA (weak/strong) x ELISA $(+/-): \kappa=0.670(\mathrm{p}<0.001)$; MEIA (weak/strong) x ELISA (weak/ strong): $\kappa=0.539(\mathrm{p}<0.001)$

Table 2

Frequency of risk factors associated with human immunodeficiency virus (HIV) infection among subjects with hepatitis C virus (HCV)-RNA detected by the polymerase chain reaction (PCR)

\begin{tabular}{|c|c|c|c|c|c|}
\hline Risk factor & $\begin{array}{c}\mathrm{HIV}(+) \\
(\mathrm{n}=96) \\
\mathrm{N}^{2}(\%)\end{array}$ & $\begin{array}{c}\mathrm{HIV}(-)^{1} \\
(\mathrm{n}=15) \\
\mathrm{N}^{2}(\%)\end{array}$ & OR & $95 \% \mathrm{CI}$ & $p^{*}$ \\
\hline \multicolumn{6}{|l|}{ Parenteral } \\
\hline Intravenous drug user & $50(52.1)$ & $1(6.7)$ & 15.22 & $1.92-120.35$ & $<0.001$ \\
\hline Blood transfusion & $14(14.6)$ & $5(33.3)$ & 0.34 & $0.10-1.15$ & 0.131 \\
\hline \multicolumn{6}{|l|}{ Sexual } \\
\hline Multiple partners ${ }^{3}$ & $57(59.4)$ & $3(20.0)$ & 5.85 & $1.55-22.09$ & 0.004 \\
\hline Male homosexual & $11(11.5)$ & $0(0.0)$ & - & - & - \\
\hline Drug user partner ${ }^{4}$ & $6(6.3)$ & $0(0.0)$ & - & - & - \\
\hline Not identified & $5(5.2)$ & $8(53.3)$ & 0.05 & $0.01-0.19$ & $<0.001$ \\
\hline
\end{tabular}

${ }^{1}$ blood donors (7) + patients with chronic hepatitis C $(8) ;{ }^{2}$ number of subjects who presented the risk factor; ${ }^{3}$ more than 10 lifetime sexual partners; ${ }^{4}$ subject who is not a drug user; OR: odds ratio; CI: confidence interval; *p $<0.05$ 
VOGLER, I.H.; NISHIYA, A.; MORIMOTO, H.K.; REICHE, E.M.V.; BORTOLIERO, A.L.; MATSUO, T.; SABINO, E.C. \& VAZ, A.J. - Serological, epidemiological and molecular aspects of hepatitis C virus infection in a population from Londrina, PR, Brazil, 2001-2002. Rev. Inst. Med. trop. S. Paulo, 46(6):303-308, 2004.

\section{DISCUSSION}

Retesting MEIA reactive samples by a second ELISA showed that the agreement between the two methods was higher in the chronic hepatitis $\mathrm{C}$ group and HIV-positive subjects than in blood donors. Since all MEIA and ELISA reactive samples submitted to PCR showed a positive result, one may suppose that a reactive result by two different screening tests indicates that the detected antibodies are anti-HCV specific. The use of a second ELISA for confirmation of anti-HCVpositive results has first been proposed as an applicable strategy to reduce the use of supplemental tests in up to $85 \%$ of cases found in a clinical laboratory ${ }^{14}$.

The level of reactivity in the anti-HCV antibody screening test is related to the positivity in PCR. A PCR-positive result was observed in $86.8 \%$ of samples with a strong reactivity by MEIA, in contrast to only $13.6 \%$ of samples with weak reactivity by MEIA that presented detectable HCV-RNA. In a similar study, $71 \%$ of samples with a S/CO ratio higher than 3.0 in ELISA and 50\% of the samples with a S/CO ratio between 1.0 and 3.0 tested positive by $\mathrm{PCR}^{15}$. Another study reported $91.5 \%$ positivity in PCR when the S/CO ratio in ELISA was higher than 3.0 and only $17.6 \%$ when the $\mathrm{S} / \mathrm{CO}$ ratio was between 1.0 and $3.0^{11}$.

The procedure employed for the determination of the genotype of the samples evaluated was nucleotide sequencing of 5'-UTR. Although this is the most conserved region of the HCV genome, it is polymorphic enough for genotype differentiation of clinical specimens and has the advantage of using the same PCR amplification product generated in viremia detection tests, thus reducing laboratory costs. Difficulties in the differentiation between subtypes $1 \mathrm{a}$ and $1 \mathrm{~b}$ and subtypes $2 \mathrm{a}$ and $2 \mathrm{~b}$ were observed for some samples. A study comparing sequencing of the 5'-UTR and NS5 regions showed that $3.4 \%$ of strains classified as $1 \mathrm{a}$ by 5 '-UTR sequencing were $1 \mathrm{~b}$ when the NS5 region was sequenced, and $25 \%$ of those classified as $1 \mathrm{~b}$ by $5^{\prime}$-UTR analysis resulted in 1a when sequencing the NS5 region ${ }^{10}$. Nevertheless, this fact does not invalidate the method since for therapeutic purposes determination of the main types is sufficient ${ }^{1}$.

In the present study, most samples were identified as HCV genotype 1 , with a predominance of subtype 1a followed by subtype $1 \mathrm{~b}$. These results are in agreement with the literature, with genotype 1 being the most common HCV genotype in North and South America, Europe and $\mathrm{Asia}^{27}$. In a previous study carried out in a Brazilian population consisting of different $\mathrm{HCV}$ exposure categories, genotype 1 was detected in $72 \%$ of the subjects, type 2 in $2 \%$, type 3 in $25.3 \%$, and type 4 in $0.7 \%$. Differences in the distribution profile of the $\mathrm{HCV}$ subtypes in the different geographical regions of Brazil have been reported, with subtype $1 \mathrm{~b}$ being the most prevalent in the southeast area followed by subtype 1a, subtypes $1 \mathrm{~b}$ and $3 \mathrm{a}$ being the most frequent in the northeast area, and subtype 1a being the most common in the center-west region, followed by subtype $3 \mathrm{a}^{18}$.

The frequency of risk factors was evaluated in patients with active infection, evidenced by a PCR-positive result $(n=111)$. These data did not differ significantly from that found in all anti-HCV-reactive subjects ( $\mathrm{n}=183$; data not shown). Nevertheless, the use of HCVRNA-positive subjects might allow a better analysis of the results, with the exclusion of false-positive cases which are very common among blood donors.

A large number of subjects who admitted to have a sexual risk behavior or who were intravenous drug users were observed in the group co-infected with HCV and HIV. This finding agrees with previous observations made in HIV-seropositive patients from Rio de Janeiro, Brazil, where at least $70 \%$ of the subjects have been demonstrated to be engaged in high risk sexual activity and $70 \%$ of intravenous drug users were infected with $\mathrm{HCV}^{22}$. In HIV/HCV co-infected patients from São Paulo, Brazil, intravenous drug use was also the main risk factor detected ${ }^{20}$.

The number of subjects in whom the infection source was associated with blood transfusion was small when compared to those with intravenous drug use as risk factor. Data reported by the Centers for Disease Control and Prevention (CDC, USA) indicate blood transfusion as the main cause of infections acquired more than 10 years ago. The number of cases associated with intravenous drug use is increasing, and currently accounts for $60 \%$ of $\mathrm{HCV}$ transmission in the United States ${ }^{3}$.

The number of subjects with unknown source of infection was high, especially among blood donors and patients with chronic hepatitis C. In a community-based survey carried out in the State of Mato Grosso, Brazil, 78.9\% of anti-HCV-reactive subjects did not present any evident risk factor for exposure to the virus, which was attributed to the fact that the group consisted of healthy subjects who probably could not remember such an important fact as a blood transfusion during childhood $^{25}$. Risk factors related to HCV infection could not be detected in 5.2\% of HIV/HCV co-infected patients, a rate similar to that observed in São Paulo, where $5.4 \%$ of HIV/HCV patients also denied any possible route of infection ${ }^{20}$.

Although the serological, epidemiological and molecular aspects of $\mathrm{HCV}$ infection here obtained are related to a small population, this study was justified by the lack of information about HCV infection in the Londrina region, Paraná. Thus, it demonstrated the importance to continue this study in order to establish routine procedures that can be applied to the screening and confirmation of the diagnosis, as well as to provide an applied methodology for the epidemiological investigation of the virologic profile and therapeutic monitoring of $\mathrm{HCV}$-infected patients.

\section{RESUMO}

\section{Aspectos sorológicos, epidemiológicos e moleculares da infecção pelo vírus da hepatite $\mathrm{C}$ na população da região de Londrina, Paraná, Brasil, 2001-2002}

Aspectos sorológicos, epidemiológicos e moleculares da infecção pelo vírus da hepatite C (HCV) foram avaliados em 183 indivíduos da região de Londrina, Paraná. Amostras soropositivas para anti-HCV pelo enzimaimunoensaio de micropartículas (MEIA), provenientes de oito pacientes com hepatite C crônica, 48 doadores de sangue e 127 indivíduos infectados pelo vírus da imunodeficiência humana (HIV), foram submetidas ao enzimaimunoensaio (ELISA) e a reação em cadeia da polimerase (PCR). Em 78,7\% das amostras, verificou-se resultado 
VOGLER, I.H.; NISHIYA, A.; MORIMOTO, H.K.; REICHE, E.M.V.; BORTOLIERO, A.L.; MATSUO, T.; SABINO, E.C. \& VAZ, A.J. - Serological, epidemiological and molecular aspects of hepatitis C virus infection in a population from Londrina, PR, Brazil, 2001-2002. Rev. Inst. Med. trop. S. Paulo, 46(6):303-308, 2004.

reagente no ELISA, ocorrendo maior proporção de resultados discordantes entre doadores de sangue $(70,8 \%)$. O mesmo ocorreu com a pesquisa do RNA viral, na qual 111/165 (67,3\%) amostras foram positivas com PCR, verificando-se maior positividade entre indivíduos HIV soropositivos e pacientes com hepatite crônica do que em doadores de sangue. Em 61 amostras com viremia detectável, realizou-se a genotipagem do $\mathrm{HCV}$, encontrando-se os genótipos $1(77,1 \%), 3$ $(21,3 \%)$ e $2(1,6 \%)$. Por fim, foram avaliados os fatores epidemiológicos em indivíduos com infecção ativa, nos quais o uso de drogas injetáveis foi o principal fator de risco encontrado em indivíduos co-infectados pelo HIV/HCV e a transfusão sangüínea foi o mais comum em indivíduos sem infecção pelo HIV. O presente estudo contribuiu para o conhecimento do perfil da infecção pelo HCV em indivíduos da nossa população e da distribuição dos genótipos do HCV nesta região.

\section{ACKNOWLEDGMENTS}

We thank Adriana Georgeto, M.D., Arilson Akira Morimoto, M.D. (Department of Infectious Diseases, Universidade Estadual de Londrina), Cristina Faune, M.D. and Denise Mashima, M.D. (Hemocentro Regional de Londrina) for providing the patients.

\section{REFERENCES}

1. ARENS, M. - Clinically relevant sequence-based genotyping of HBV, HCV, CMV and HIV. J. clin. Virol., 22: 11-29, 2001.

2. CARNEIRO, M.A.S.; MARTINS, R.M.B.; TELES, S.A. et al. - Hepatitis C prevalence and risk factors in hemodialysis patients in Central Brazil: a survey by polymerase chain reaction and serological methods. Mem. Inst. Oswaldo Cruz, 96: 765-769, 2001.

3. CENTERS FOR DISEASE CONTROL AND PREVENTION - Recommendations for prevention and control of hepatitis $\mathrm{C}$ virus (HCV) and $\mathrm{HCV}$-related chronic disease. M.M.W.R., 47 (RR-19): 1-39, 1998

4. CHOMCZYNSKI, P. \& SACCHI, N. - Single-step method of RNA isolation by acid guanidinium thiocyanate-phenol-chloroform extraction. Anal. Biochem., 162: 156159, 1987.

5. DEN BRINKER, M.; WIT, F.W.; WERTHEIM-van DILLEN, P.M. et al. - Hepatitis B and $\mathrm{C}$ virus co-infection and the risk for hepatotoxicity of highly active antiretroviral therapy in HIV-1 infection. Aids, 14: 2895-2902, 2000.

6. DIETERICH, D.T. - Hepatitis $\mathrm{C}$ virus and human immunodeficiency virus: clinical issues in coinfection. Amer. J. Med., 107: 79S-84S, 1999.

7. ERENSOY, S. - Diagnosis of hepatitis $\mathrm{C}$ virus (HCV) infection and laboratory monitoring of its therapy. J. clin. Virol., 21: 271-281, 2001.

8. FOCACCIA, R.; CONCEIÇÃO, O.J.; SETTE-Jr., H. et al. - Estimated prevalence of viral hepatitis in the general population of the municipality of São Paulo, measured by a serologic survey of a stratified, randomized and residence-based population. Braz. J. infect. Dis., 2: 269-284, 1998.

9. GARSON, J.A.; TEDDER, R.S.; BRIGGS, M. et al. - Detection of hepatitis C viral sequences in blood donations by "nested" polymerase chain reaction and prediction of infectivity. Lancet, 335: 1419-1422, 1990.

10. GERMER, J.J.; RYS, P.N.; THORVILSON, J.N. \& PERSING, D.H. - Determination of hepatitis $\mathrm{C}$ virus genotype by direct sequence analysis of products generated with the Amplicor HCV test. J. clin. Microbiol., 37: 2625-2630, 1999.
11. GONÇALES, N.S.L.; COSTA, F.F.; VASSALLO, J. \& GONÇALES-Jr., F.L. - Diagnosis of hepatitis $\mathrm{C}$ virus in Brazilian blood donors using a reverse transcriptase nested polymerase chain reaction: comparison with enzyme immunoassay and recombinant protein immunoblot assay. Rev. Inst. Med. trop. S. Paulo, 42: 263-267, 2000.

12. GONÇALES-Jr., F.L.; STUCCHI, R.S.B.; PAVAN, M.H.P. et al. - A clinical, epidemiological, laboratorial, histological and ultrasonographical evaluation of antiHCV EIA-2 positive blood donors. Rev. Inst. Med. trop. S. Paulo, 42: 147-152, 2000 .

13. GÓNGORA, D.V.N. - Marcadores sorológicos da infecção pelo vírus da hepatite C em trabalhadores e pacientes da Unidade de Diálise do Hospital das Clínicas da Faculdade de Medicina da Universidade de São Paulo. Rev. Soc. bras. Med. trop., 31: 585$586,1998$.

14. GOUBAU, P.; REYNDERS, M.; BEUSELINCK, K. et al. - Confirmatory strategy of hepatitis $\mathrm{C}$ serology based on two screening assays in a diagnostic setting. Acta clin. belg., 52: 31-35, 1997.

15. GRETCH, D.; LEE, W. \& COREY, L. - Use of aminotransferase, hepatitis C antibody, and hepatitis $\mathrm{C}$ polymerase chain reaction RNA assays to establish the diagnosis of hepatitis $\mathrm{C}$ virus infection in a diagnostic virology laboratory. J. clin. Microbiol., 30: 2145-2149, 1992.

16. KIYOSAWA, K.; SODEYAMA, T.; TANAKA, E. et al. - Interrelationship of blood transfusion, non-A, non-B hepatitis and hepatocellular carcinoma: analysis by detection of antibody to hepatitis C virus. Hepatology, 12: 671-675, 1990.

17. KRAMER, M.S. \& FEINSTEIN, A.R. - Clinical biostatistics. LIV. The biostatistics of concordance. Clin. Pharmacol. Ther., 29: 111-123, 1981.

18. MARTINS, R.M.B.; VANDERBORGHT, B.O.M. \& YOSHIDA, C.F.T. - Hepatitis C virus genotypes among blood donors from different regions of Brazil. Mem. Inst. Oswaldo Cruz, 93: 299-300, 1998

19. McHUTCHISON, J.G.; GORDON, S.C.; SCHIFF, E.R. et al. - Interferon alpha-2b alone or in combination with ribavirin as initial treatment for chronic hepatitis C. Hepatitis Interventional Therapy Group. New Engl. J. Med., 339: 1485-1492, 1998.

20. MENDES-CORREAA, M.C.; BARONE, A.A. \& GUASTINI, C. - Hepatitis C virus seroprevalence and risk factors among patients with HIV infection. Rev. Inst. Med. trop. S. Paulo, 43: 15-19, 2001.

21. OLIVEIRA, M.L.A.; BASTOS, F.I.; SABINO, R.R. et al. - Distribution of HCV genotypes among different exposure categories in Brazil. Braz. J. med. biol. Res., 32: 279282, 1999.

22. OLIVEIRA, M.L.A.; BASTOS, F.I.; TELLES, P.R. et al. - Prevalence and risk factor for $\mathrm{HBV}, \mathrm{HCV}$ and $\mathrm{HDV}$ infections among injecting drug users from Rio de Janeiro, Brazil. Braz. J. med. biol. Res., 32: 1107-1114, 1999.

23. PONTELLO, R.; REICHE, E.M.V.; INOUYE, M.M.Z. \& SOUZA, J.L.K. - Frequiência de positividade dos marcadores sorológicos dos vírus de hepatite A, B e C em 500 candidatos a doadores de sangue do Hemocentro do Hospital Universitário Regional Norte do Paraná, Londrina, PR. Rev. bras. Anal. clín., 25: 7-10, 1993.

24. REICHE, E.M.V; MORIMOTO, H.K.; FARIAS, G.N et al. - Prevalência de tripanossomíase americana, sífilis, toxoplasmose, rubéola, hepatite $\mathrm{B}$, hepatite $\mathrm{C}$ e da infecção pelo vírus da imunodeficiência humana, avaliada por intermédio de testes sorológicos, em gestantes atendidas no período de 1996 a 1998 no Hospital Universitário Regional Norte do Paraná. Rev. Soc. bras. Med. trop., 33: 519-527, 2000

25. SOUTO, F.J.D.; FONTES, C.J.F.; MARTELLI, C.M.T. et al. - Hepatitis C virus prevalence among an immigrant community to the southern Amazon, Brazil. Mem. Inst. Oswaldo Cruz, 94: 719-723, 1999 
VOGLER, I.H.; NISHIYA, A.; MORIMOTO, H.K.; REICHE, E.M.V.; BORTOLIERO, A.L.; MATSUO, T.; SABINO, E.C. \& VAZ, A.J. - Serological, epidemiological and molecular aspects of hepatitis C virus infection in a population from Londrina, PR, Brazil, 2001-2002. Rev. Inst. Med. trop. S. Paulo, 46(6):303-308, 2004.

26. SULKOWSKI, M.S.; THOMAS, D.L.; CHAISSON, R.E. \& MOORE, R.D. Hepatotoxicity associated with antiretroviral therapy in adults infected with human immunodeficiency virus and the role of hepatitis C and B virus infection. J. Amer. med. Ass., 283: 74-80, 2000

27. TAYLOR, D.R.; SHI, S.T. \& LAI, M.M.C. - Hepatitis C virus and interferon resistance. Microbes Infect., 2: 1743-1756, 2000.

28. TONG, M.J.; EL-FARRA, N.S.; REIKES, A.R. \& CO, R.L. - Clinical outcomes after transfusion-associated hepatitis C. New Engl. J. Med., 332: 1463-1466, 1995.
29. VANDERBORGHT, B.O.M.; ROUZERE, C.; GINUINO, C.F. et al. - High prevalence of hepatitis $\mathrm{C}$ infection among Brazilian hemodialysis patients in Rio de Janeiro: a one-year follow-up study. Rev. Inst. Med. trop. S. Paulo, 37: 75-79, 1995.

30. WHO \& THE VIRAL HEPATITIS PREVENTION BOARD - Global surveillance and control of hepatitis C. J. viral Hepatitis, 6: 35-47, 1999.

Received: 4 June 2004

Accepted: 4 October 2004 